\title{
CHEMICAL PROPERTIES, MICROBIOLOGY AND ANTIOXIDANT ACTIVITYOF ABON BEEF IN THE CITY OF PALU
}

\author{
Sukisman Abdul Halid ${ }^{1}$ ) and Abdul Rahim ${ }^{2}$ \\ ${ }^{1)}$ Development and Innovation Research Institute of Central Sulawesi Province. Dr. Suharso street No. 14 Palu 94112 \\ Central Sulawesi, Email : kismanfarm@yahoo.co.id \\ ${ }^{2)}$ Major of Agricultural Technology, Agrotechnology Study Program, Faculty of Agriculture, Tadulako University. \\ Jalan Soekarno Hatta Km. 9 Palu 94118 Central Sulawesi.
}

\begin{abstract}
One of the most popular food products in Central Sulawesi is shredded beef, and sometimes aspects of food quality and safety were not given attention by producers or consumers. The objective of the study is to identify the chemical, microbiological and antioxidant properties of shredded beef produced and circulated in Palu City. This study uses a complete randomized design with 8 samples and each sample were repeated three times so that 24 samples were obtained with observed parameters including moisture content, ash content, protein content, fat content, total microbial count and antioxidant activity.The results showed that water content $(5,04-9,35 \%)$, ash content $(3,59-5,74 \%)$, protein content $(25,60-38,97 \%)$, fat content $(19,20-39,37 \%)$ and total microbial count $(1,27-8,48 \mathrm{log} \mathrm{cfu} / \mathrm{g})$ and antioxidant activity as indicated by Inhibition Concentration / IC50 (3234,31 - 6740,5 ppm) and percentage of inhibition (35,63 - 80.27\%). The results of this study indicate that shredded beef from various SMEs in the city of Palu is still partially met the quality standards based on SNI, so MSME guidance is needed periodically and continuously.
\end{abstract}

Keywords: Abon beef, Antioxidant activity, Physiochemical properties.

\section{INTRODUCTION}

One of the known processed products is the cow's shredded beef of processed meat products which are shredded or finely dressed and added with spices according to taste and then fried. The meat commonly used for making abon is beef. However, all types of meat including chicken, pork, fish, etc. can be used as raw material for making abon. Abon making generally uses spices/seasoning that varies between one manufacturer with others, so the aroma and flavor also vary. Spices are an additional ingredient of Indonesian society and are widely used as a spice in traditional food preparations to enhance aroma, flavor, antimicrobial, and antioxidant (Rahayu, 2000). Spices generally contain antioxidant compounds and can interact with physiological reactions, thus having antimicrobial activity (Chukwu and
Imodiboh, 2009). Antioxidant compounds are commonly found in fruit, vegetable and spice group foods (Pokorny, 2008).

In Palu City, Central Sulawesi, abon beef is produced by producers, with different types and composition of herbs and spices used, so the physicochemical properties, total microbes, and antioxidant activity need to be known. Therefore, it is necessary to study about the physicochemical properties, total microbial, and the antioxidant activity of abon beef circulating in Palu City. The purpose of the research is to analyze the physicochemical properties, and total microbial and antioxidant activity of abon beef circulating in Palu City. quality of meat abon based on Indonesian National Standard (SNI) with SNI 01-3707 1995 (2003).

Abon is a processed meat product that issusceptible to oxidation. Fatty oxidation is one of the main causes of the 
decline in the quality of meat products (Gadekar et al., 2010), causing rancidity, therefore,it requires bioactive compounds that have antioxidant effects (Lund et al., 2007). The antioxidants in food are defined as substances used for food preservation, in order to slow the occurrence of oxidative food damage (Kumar, 2011), suppress the occurrence of sensory quality changes (color, texture, and taste) due to oxidation (Antolovich et al., 2002).

Making abon in the city of Palu generally use spices and seaoning, suchas galangal (Alpinia galanga Swart). Galangal has potential as a source of nutrients, traditional medicine, antioxidants, as well as improving the attributes of quality and taste of food (Stankevičius et al., 2010), and has a strong inhibitory effect on Staphylococcus aureus and Bacillus cereus (Verma et al., 2011). The next spice is red onion widely used as a spice for various dishes because of its aroma and flavor, and contains various phytochemicals including antioxidants (Hedges and Lister, 2007). The next spice is garlic (Allium sativum, L) which has long been used as one of the spices by the community because of its distinctive aroma, has antioxidant activity, as well as traditional medicine for people for various diseases such as respiratory and nerve disorders (Leelarungrayub et al., 2004 ). Furthermore, Javanese tamarind is commonly used as a mixture of cooking spices (Caluwé et al., 2010).

In making abon,sometimessugar is also added to improve the texture and add abon flavor (Fachruddin, 1997). The types of sugars commonly added in food processing are brown sugar and/or plain sugar (Phillips et al., 2009). Furthermore, the kitchen salt $(\mathrm{NaCl})$ is an additional material that is always used in cooking food (Purnomo, 1997). The addition of salt in processed foods is a preservation method that can extend the store life of processed food (Islam et al., 2009; Singh et al., 2010). It is reported that salt in processed foods provides an important role in improving flavor and taste characteristics (Weiss et al., 2010), palatability and consumer tastes (Liem et al., 2011).

Furthermore, the measurement of antioxidant activity in processed meat products is very important. According to Velasco and Williams (2011) the nutritional value and quality of processed meats can be improved by using natural antioxidant compounds that can reduce microbial growth and fat oxidation during storage. The method used in the testing of antioxidant activity is the free radical 1,1diphenyl - 2 -picrylhydrazil (DPPH) free radical uptake measured at a wavelength of $517 \mathrm{~nm}$ which is the maximum wavelength of DPPH. Testing of antioxidant activity is one of the simplest method of using DPPH.DPPH is a stable free radical compound that interprets the test results with DPPH method is the antioxidant activity and percentage of inhibition (sample inhibition) against free radical DPPH (Molyneux, 2004).

Referring to the description, a research has been conducted that aims to (a) to know the chemical, microbiological, and antioxidant activity of abon beef produced by micro small producer (MSME) in Palu City and (b) to know the abon beef that has not fulfilled SNI.

\section{MATERIALS AND METHODS}

Time, place, materials and tools. This research was conducted in May - June 2017 at Palu City, Central Sulawesi. Central Laboratory of Biological Sciences, Brawijaya University, Malang, East Java, as a place for analysis of water content, ash, protein, fat and total microbial, as well as Central Laboratory, Pajajaran University, West Java, as a place of analysis of antioxidant activity.

The main ingredients of the research are abon beef obtained from abon beef business abusers circulating in Palu City. The research tools are box samples, blue ice and stereofoam which are used as sampling tools and sample delivery to be analyzed at 
Sentry Laboratory of Biological Sciences, Universitas Brawijaya, Malang, East Java. Analyzer such as erlenmeyer, analytical scale, K-Jedhal flask, water bath, extraction flask, desiccator, distillation soxhlet, oven, oven, vortex, autoclave, blue type micropipette, measuring flask, test tube, stative, glass beaker, , crepe paper, plastics, jump bottles, ropes and porcelain cups.

Research methods. This research used laboratory explorative method which was analyzed descriptively and analytically. Implementation of business survey of abon beef in Palu City based on Iqbal (2008) method is research conducted on a number of individuals / units in order to obtain facts from factual symptoms in the field.

The sample of this research wasabon beef circulating in Palu City area. The determination of the sample was done by Purposive random Sampling (Nasir, 2005). Sampling was conducted on eight actors of UMKM spread in Palu City and every UMKM was taken three times production as replication. The sampling code of each UMKM is UMKM 1, 2, 3, 4, 5, 6, 7 and 8. The criteria for sampling abon beef on UMKM is based on (i) strategic and easy to reach location, (ii) location of the sale of shredded beef is located in the depot / shop and settle (not the cart trader / pavement), (iii) cleanliness of the / depot / shop that includes the floor, tables, processing equipment, etc. and (iv) the location of abon beef sale is already popular among the people of Palu City.

This study used a Completely Randomized Design (RAL) consisting of eight (8) treatments ie abon samples of UMKM beef 1, 2, 3, 4, 5, 6, 7 and 8. Each treatment was repeated 3 times so that there were 24 units of observation. The data obtained were analyzed by the analysis method of variance. If any effect was present, it will be continued with Duncan Multiple Range Test (Steel and Torrie, 1981).

Observation parameters. Analysis of the chemical, microbiological and antioxidant properties of abon beef include moisture content (AOAC, 2000), ash content (AOAC, 2000), protein content (AOAC, 2000), fatty content (AOAC, 2000), microbiological tests (Pettipher, 1999 ) and antioxidant activity (Tangkanakul et al., 2009).

\section{RESULTS AND DISCUSSION}

Abon beef Water content. Abon beef produced by UMKM that were spread in Palu City gives a real influence on water content. The highest average water content $(9,35+0,09 \%)$ was obtained in sample abon UMKM 2 and the lowest (5.04+ $0,52 \%$ ) at UMKM 5 (Figure 1), where sample of abon UMKM 2 was different with all abon samples.

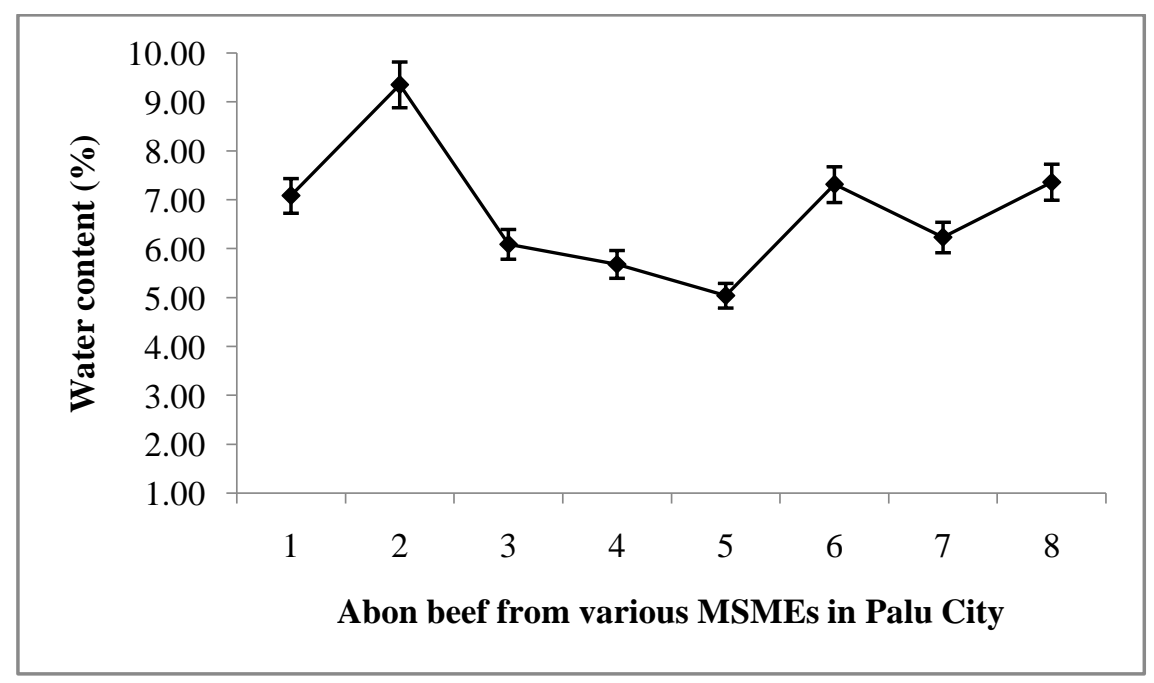

Figure 1. Water content of abon beeffrom various MSMEs in Palu City. 
The results of Ockerman and $\mathrm{Li}$ (1999) showed that the water content that pork abon produce is about $3.47-5.23 \%$. Furthermore, Ogunsola and Omojola (2008) who studied the making of abon beef (danbunama) in Nigeria obtained water content ranging from $6.50-7.37 \%$. Other researchers, namely Leksono and Syahrul (2001) who examined the making of fish abon and obtained abon water content ranged from 3.64 to $9.78 \%$. The difference of water content of samples of abon beef inproduction 8 UKMN circulating in Palu City is suspected due to different processing process that is starting from boiling meat, slicing, frying temperature and different frying time.

Abon beefash level. Abon beef produced by UMKM spread in Palu City gives a real effect to ash content. The highest average ash content $(5.74+0.02 \%)$ was obtained on the sample of UMKM 6 and the lowest abon $(3.59+0.04 \%)$ in MSME 3 as shown in Figure 2. abon Sample of UMKM 6 were distinctly different with abon sample UMKM 1, 3 and 7, but not with samples abon UMKM 2, 4, 5 and 8. The difference of ash content of each sample of UMKM 8 production abon in Palu City is due to differences in the use of raw materials of beef and boneless. However, the quality requirement for abon based on SNI 01-3707 -1995 states that the maximum ash content is $7 \%$.

When compared to the level of UMKM 8 production abon beef ash in the area of Palu City with the requirement of abon quality based on SNI 01-3707-1995 is still meet the quality standard. Eiliyasmi and Marnzah (1997) reported that in line of food diversification has studied the utilization of rhizome in the manufacturing of abon with the addition of the fish as a source of protein. The results of these studies indicate that the resulting content of fish ash content is different because the fish are used without bones.

Abon Beef protein level. Abon beef produced by UMKM spread in Palu City has real effect on protein content. The highest average protein content (38,97+ $0,92 \%$ ) was obtained on sample of UMKM 7 and lowest $(25,60+0,58 \%)$ at UMKM 6 as shown in Figure 3. The sample of abon UMKM 7 is different with samples abon UMKM 1 and 6, but not with samples abon UMKM 2, 3, 4, 5 and 8.

The results of the Ogunsola and Omojola studies (2008) showed that the highest protein content (38.92-41.21\%) was obtained in abon beef (danbunama) in Nigeria, and the next highest protein content was $34.09-42.90 \%$ is pork abon from Ockerman and Li (1999). The difference of abon beef protein level forUKMN 8 production circulating in Palu City is suspected because of the difference of the addition of spices and the use of coconut milk with different composition, so the protein of spices and coconut milk is supposed to increase abon protein level.

Abon beef fat content . Abon beef produced by UMKM spread in Palu City has real effect on fat content. The highest average fat content $(39.37+1.15 \%)$ was obtained on the sample of UMKM 6 and the lowest abon $(19.20+0.81 \%)$ in UMKM 4 (Figure 3), where the sample of abon UMKM 7 was different with all existing abon samples. The difference of fat content of abon sample of UMKN 8 production in Palu City may be caused by fat content of meat as raw material in making abon and abon oil content produced when the abon is being drain-pressed. In addition, it is possible that the pressing of the abon is carried out in a cold state, causing an imperfect oil spill which causes some parts of cooking oil to be retained in the abon mass.

The results of Ogunsola and Omojola (2008) showed that the shredded beef (danbunama) in Nigeria had a fat content of $35.57-40.85 \%$. Chang and Huang (1991) also reported that zousoon in Taiwan has a fat content of $43 \%$. According to Huda et al. (2012) on the making of abon (serunding in Malaysia), reported that the variations in the resulting abon oil content are dependent on the way the incision and the pressing of the abon. 


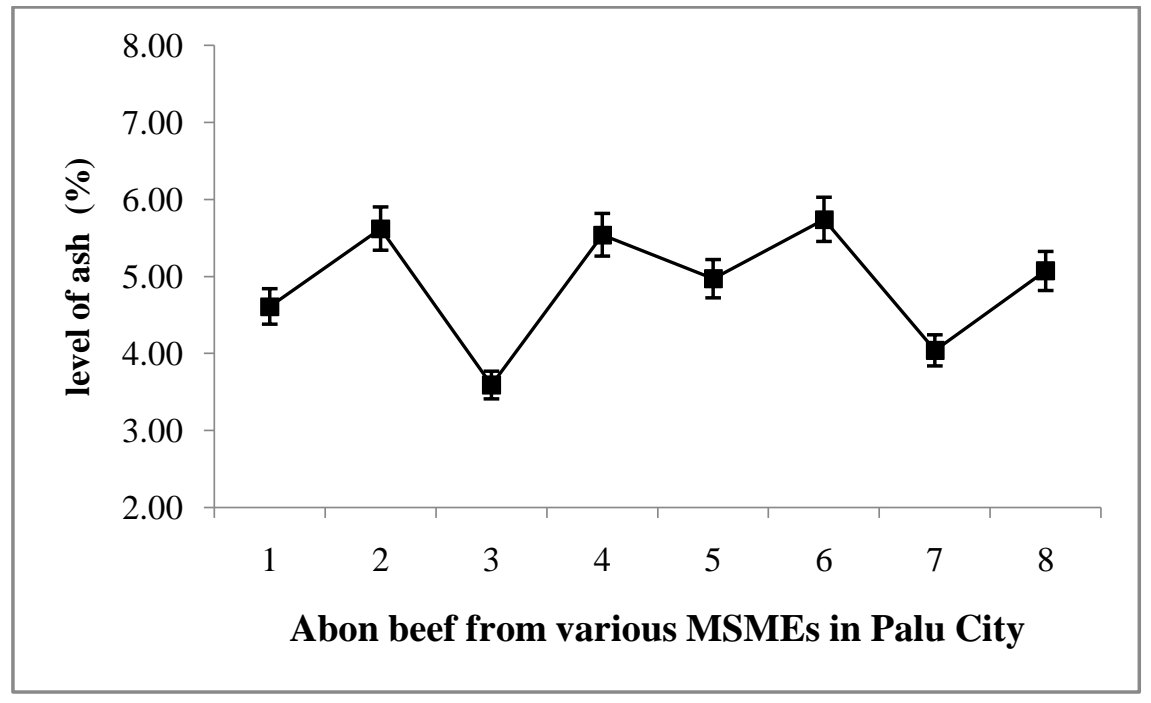

Figure 2. The level of ash Abon beef from various kinds of UMKM in Palu City.

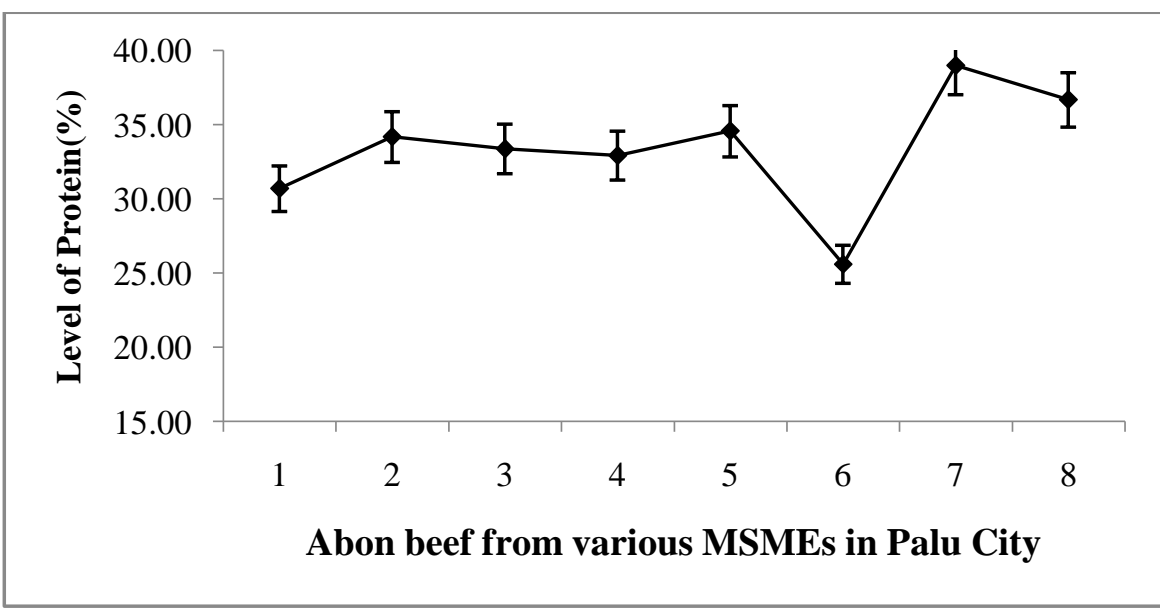

Figure 3. Level of protein content of beef from various MSMEs in Palu City.

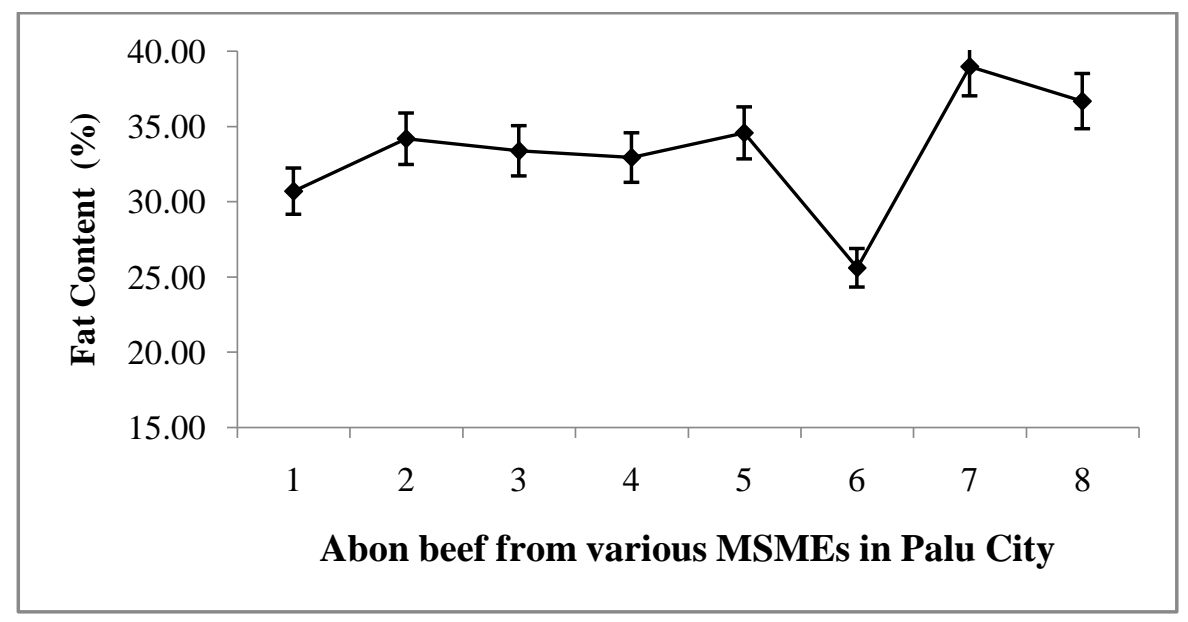

Figure 4. Fat content of Abon beef from various MSMEs in Palu City. 


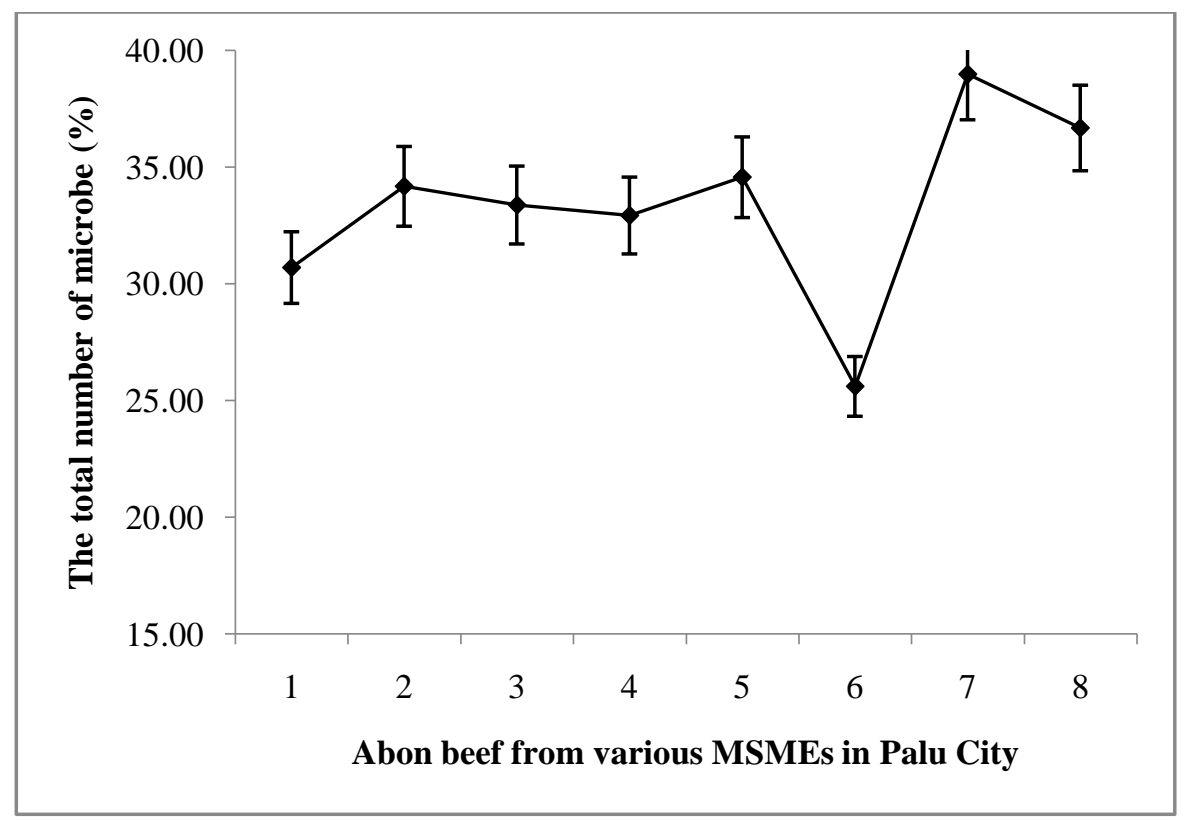

Figure 5. The total number of microbe abon beef from various MSMEs in Palu City.

Total microbe of abon beef. Abon beef produced by UMKM that were spread in Palu City has a significant effect on the total amount of microbes. The highest total microbial average $(8.48+0.21 \mathrm{log} \mathrm{cfu} / \mathrm{g})$ was obtained on samples of UMKM abon 5 and lowest $(1,33+0.05 \log \mathrm{cfu} / \mathrm{g})$ on MSME 2 (Figure 5) UMKM 5 is markedly different from all existing abon samples. Ockerman and $\mathrm{Li}$ (1999) reported the results of the study that the total number of microbial of pork abon ranged from 2.01 $2.18 \mathrm{log} \mathrm{cfu} / \mathrm{g}$. The difference in the total number of microbial samples abon production 8 UKMN in Palu city allegedly because the spices used for the manufacture of abon beef have limited inhibitory power to microbes, so the use of spices in combination with other herbs need appropriate formulation.

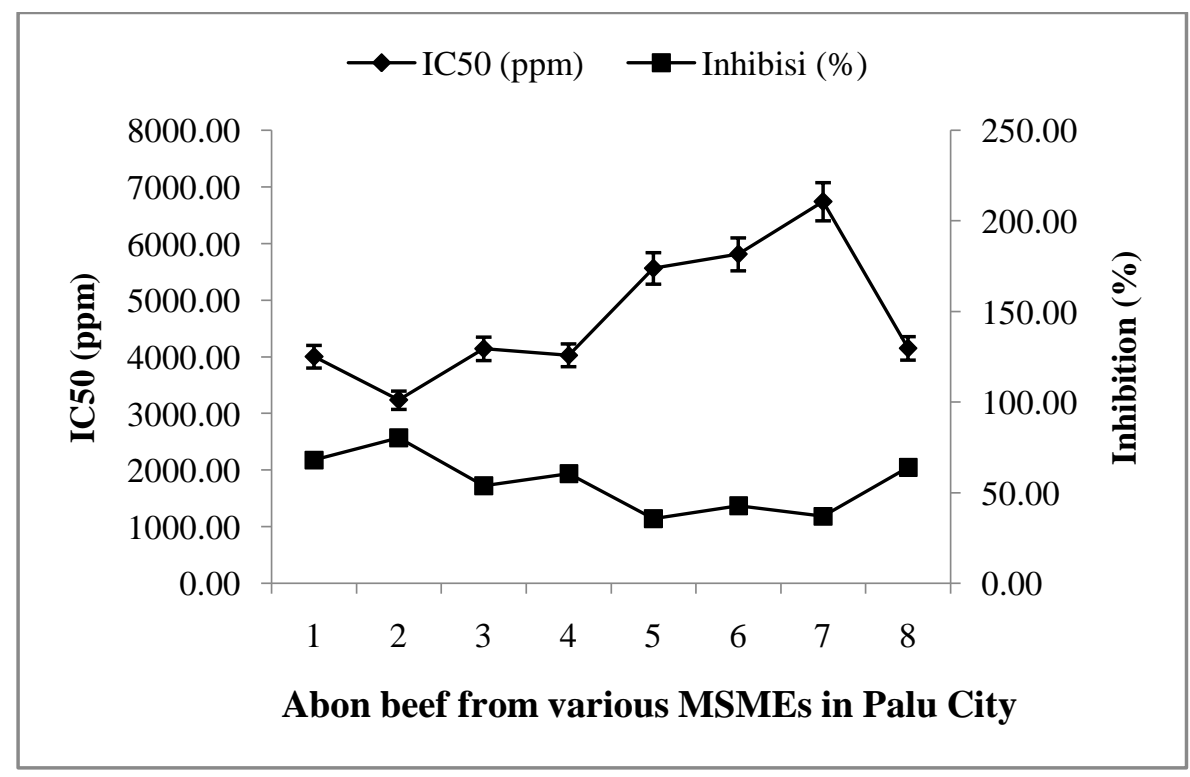

Figure 6. Antioxidant activity of chicken meat abon from various MSMEs in Palu City. 
Abon beef antioxidant activity - Abon beef produced by UMKM which were scattered in Palu City has a significant effect on antioxidant activity as shown in Figure 6. The highest antioxidant activity is obtained on samples of abon UMKM 2 which is shown with low concentration of IC50 that is $3234,41+0,38 \mathrm{ppm}$ with a high percentage of inhibition that is equal to $80.27 \%$. Measurement of antioxidant activity of abon beef using DPPH. Shih et al. (2005) reported that the use of DPPH has been generally used as a free radical detector of plant and food samples with usage of up to $60 \%$. Kim et al. (2011) reported that the use of DPPH in the evaluation of antioxidant activity in plant samples was also widely used in evaluating antioxidant activity in food products and their preparations.
According to Molyneux (2004) that the antioxidant activity test of food using DPPH as its detection compound, is because DPPH is a free radical compound that is stable, and easily react with hydrogen atoms derived from an antioxidant compound (food product) in forming reduced DPPH compound.

\section{CONCLUSION}

1. Abon beef produced by UMKM in Palu City has different chemical, microbiological and antioxidant activity.

2. Abon beef from UMKM 2 has the highest antioxidant activity.

3. Abon beef produced by UMKM 3, 5 and 6 has not fulfilled SNI so it needs further caring.

\section{REFERENCES}

Antolovich, M., Prenzler, P. D., Patsalides, E., McDonald, S. and Robards, K., 2002.Methods for Testing Antioxidant Activity.Analyst, 127: 183-198.

AOAC., 2000. Official Methods of Analysis of AOAC International. Horwitz, W.ed., $17^{\text {th }}$ ed. Gaitherburg, Maryland.

Caluwé, E. D., Halamová, K., and Damme, P. V., 2010. Tamarindus indica L. - A Review of Traditional Uses, Phytochemistry and Pharmacology.Afrika Focus, 23 (1): 53-83.

Chang, S.F. and Huang, T.C., 1991. Some Parameters Involved in Production of Zousoon-A Semidry, Long Fibered Pork Product.Journal of Meat Science, 30:303-325.

Chukwu, O. and Imodiboh, L.I., 2009. Influence of Storage Conditions on Shelf-Life of Dried Beef Product (Kilishi).World Journal of Agriculture Science,5(1): 34-39.

Eiliyasmi, W. dan Marnzah, N.,1997. Pemanfaatan Keluwih dalam Pembuatan Abon dengan Penambahan Ikan sebagai Sumber Protein dalam Rangka Diverstfikasi Pangan. Prosiding Seminar Teknologi Pangan, 421-427.

Fachruddin, L., 1997. Membuat Aneka Abon. Teknologi Tepat Guna, Kanisius (Anggota IKAPI), Yogyakarta.

Gadekar, Y.P., Kokane, R.D., Suradkar, US., Thomas, R., Das, A.K. andAnjaneyulu, ASR., 2010. Shelf Stable Meat Pickles- A Review.Journal International Food Research, 17: 221-227.

Hedges, L.J. and Lister, C.E., 2007.The Nutritional Attributes of Allium Species.Crop\& Food Research Confidential Report, 1814:1-44.

Huda, N., Fatma, Y., Fazillah and Adzitey, 2012. Chemical Composition, Color and Sensory Characteristics of Commercial Serundeng (Shredded Meat) in Malaysia.Pakistan Journal of Nutrition, 11 (1): 1-4. 
Iqbal, H., 2008. Analisis Data Penelitian dengan Statistik. Bumi Aksara, Jakarta.

Islam, R., Hossain, M.M., Akhter, S. and Malek, M.A., 2009. Effect of Curing on the Quality of Beef and Buffen. Bangladesh Journal of Animal Science, 38 (1-2): 92- 101.

Kim, Yang., M., Lee., O., and Kang.S., 2011.Antioxidant Activities of Hot Water Extracts from Various Spices. International Journal of Molecules Science., 12(6) : 4120-4131.

Kumar, S., 2011. Free Radicals and Antioxidants: Human and Food System. Advance Applied Science Research, 2 (1) : 129-135.

Leelarungrayub, N., Chanarat, N., and Rattanapanone, V., 2004. Potential Activity of Thai Shallot (Allium ascalonicum L.) Extract on the Prevention of Hemolysis and Glutathione Depletion in Human Erythrocyte from Oxidative Stress. Chiang Mai University Journal,3(3):225-233.

Leksono, T. dan Syahrul, 2001. Studi Mutu dan Penerimaan Konsumen Terhadap Abon ikan. Journal Natur Indonesia, III (2):178-184.

Liem, D. G., Miremadi, F., and Keast, R. S. J., 2011.Reducing Sodium in Foods: The Effect on Flavor-Review. Nutrients,3: 694-711.

Lund, M.N., Hviid, M.S., and Skibsted, L.H., 2007. The Combined Effect of Antioxidants and Modified Atmosphere Packaging on Protein and Lipid Oxidation in Beef Patties DuringChill Storage. Journal Meat Science, 76: 226-233.

Molyneux, P., 2004. The Use of the Stable Free Radical Diphenylpicrylhydrazyl (DPPH) for Estimating Antioxidant Activity. Songklanakarin Jounal Science Technology, 26 (2): 211219.

Nasir, M., 2005. Metode Penelitian. Cetakan 6. Ghalia Indonesia, Bogor.

Ockerman, H. W., and Li, C. T.,1999. The Evaluation of the Palatability of a Dehydrated Meat Product-Meat Floss. Bulletin. The Ohio State University Department of Animal Sciences, Ohio.

Ogunsola, O.O. and Omojola, A.B., 2008. Nutritional Evaluation of a Dehydrated Shredded Meat Product, (Danbunama). Pakistan Journal of Nutrition, 7(4): 554-556.

Pettipher, G.L., 1999. Microbiological Analyses, Advances in Milk Products.Champman and Hall. New York.Modern Dairy Technology, 2: 441-460.

Phillips, K. M., Carlsen, M. H., and Blomhoff, R., 2009. Total Antioxidant Content of Alternatives to Refined Sugar. Journal American Diet Associety,109: 64-71.

Pokorny, J., 2008. Application of Phenolic Antioxidants in Food Products.Electronic Journal of Environmental, Agriculture and Food Chemistry, 7 (8): 3320-3324.

Purnomo, H., 1997. Aplikasi Kromatografi Gas dalam Pengukuran Oksidasi Lemak Dendeng. Laporan Penelitian, Fakultas Peternakan, Universitas Brawijaya, Malang.

Rahayu, W. P., 2000. Aktivitas Antimikroba Bumbu Masakan Tradisional Hasil Olahan Industri Terhadap Bakteri Patogen dan Perusak. Buletin Teknologi dan Industri Pangan, XI (2) : $42-48$.

Shih, P. W., Lai, P. L., and Jen, H. W. K., 2005.Antioxidant Activities of Aqueous Extracts of Selected Plants. Journal of Food Chemistry, 775-783. 
Singh, A., Sharma, P. K.., and Garg, G., 2010. Natural Products as Preservatives. Internanational Journalof Pharmaceutic and Biology Science, 1(4): P-601- P-612.

Stankeviius ,M., Akuneca , J., Jãkobsone ,I., and Maruška, A., 2010. Analysis of Phenolic Compounds and Radical Scavenging Activities of Spice Plants Extracts. Maisto Chemija Ir Technologij, 44 (2): 85-91.

Steel, R. G. D., and Torrie, J. H., 1981. Principles and Procedures of Statistics a Biometrical Approach. Mc. Graw Hill Book Co. International Ed. Singapore.

Tangkanakul, P.,Auttaviboonkul, P., Niyomwit, B., Lowvitoon, N., Charoenthamawat, P. and Trakoontivakorn, G., 2009. Antioxidant Capacity, Total Phenolic Content and Nutritional Composition of Asian Foods After Thermal Processing. International of Food Research Journal, 16: 571-580.

Velasco, V., and Williams, P., 2011. Improving Meat Quality Through Natural AntioxidantsReview. Chilean Journal of Agriculture Research, 71(2): 313-322.

Verma, K.R., Mishra, G., Singh, P., Jha, K.K., and Khosa, R. L., 2011. Alpinia Galanga-An Important Medicinal Plant: A Review. Der Pharmacia Sinica, 2 (1): 142-154.

Weiss, J., Gibis, M., Schuh, V., and Salminen, H., 2010. Advances in Ingredient and Processing Systems for Meat and Meat Products - Review. Meat Science, 86: 96-213. 